\title{
Miasto bez schematu. Plany komunikacji miejskiej i rozwój Warszawy
}

\author{
A City without its transit map. Public transport \\ plans and the development of Warsaw
}

„Narracja interpretacyjna otaczającego nas świata” - tym, jak powiada Piotr Galik (2018: 14), jest każda mapa, każda bez wyjątku. Opiekun kartograficznego działu Zakładu Narodowego im. Ossolińskich we Wrocławiu z miejsca dodaje, że jeśli ludzie przypisują pewną obiektywność mapom, jest to rezultatem nieprzyjmowania do wiadomości, że ziemską rzeczywistość opisują one w sposób zniekształcony przez interpretację, uwarunkowaną konwencjami już to kulturowo-społecznymi, politycznymi, już graficznymi i technicznymi. A w przypadku humanistów - to już dodaje piszący te słowa - uleganie złudzeniu, że mapa odbija świat, łączy się z kompensowaniem niepokoju, iż wiedza pozyskiwana przy zastosowaniu metodologii nauk przyrodniczych bądź ścisłych jest bardziej uporządkowana i wiarygodna. Stąd zapewne wysoka pozycja problematyki mapy we współczesnych, szeroko rozumianych naukach o kulturze. Próbujemy rozpoznać zarówno skalę i rodzaj złudzeń związanych z mapami na przestrzeni wieków, jak również - skoro w wieku XX w kartografii nastąpiła specjalizacja - ogarnąć nowoczesny repertuar map tematycznych oraz, wreszcie, zgłębić efekty niedawnej rewolucji cyfrowej. Epoka, w której warszawskiemu taksówkarzowi nie mogłoby przydarzyć się kompromitujące pomylenie ulicy Koziej z Koźlą, gdyż zamiast na nawigacji satelitarnej polegałby na znajomości mapy stolicy „wgranej” w umysł, jest przecież całkiem nieodległa.

Związek nasilenia obecności map w naszym codziennym życiu z upowszechnieniem technologicznych podpórek, w tym kanałów reprodukcji materiałów kartograficznych, skutkuje przede wszystkim tym, że sporządzanie czy użytkowanie map 
stało się jedną z metafor praktyk kategoryzacyjnych i deskryptywnych (anglicyzm mapping): jak w informatyce mapowane są dyski albo pamięć operacyjna, tak mapuje się np. wrażenia i proces biznesowy w międzynarodowej korporacji; diagramy świetnie spisują się w prezentacjach multimedialnych na branżowych szkoleniach (Kalbach 2017). Co więcej, lepiej dostrzegamy różnorodność map (my - nie tylko akademicy, po prostu uczestnicy kultury współczesnej); zwracamy uwagę na mapę jako wszechobecny przekaz, gatunek obrazu i gatunek słowny, który wcale nie musi ściśle spełniać profesjonalnych kryteriów geograficzno-kartograficznej definicji mapy. $\mathrm{Na}$ tym poziomie, potocznego obcowania z obrazowaniem przestrzeni, często przechodzimy do porządku dziennego nad kluczową dla zawodowców różnicą między mapą a planem; plany nie wykorzystują współrzędnych geograficznych, nie są wyposażone w siatkę kartograficzną, ale siatkę kwadratów w opisie podobną do oznaczeń położenia na szachownicy, operującą literami i cyframi, umożliwiającymi odnalezienie wybranej ulicy czy placu.

Do czynienia z mapami mamy na afiszach, plakatach propagandowych, muralach, kubkach do kawy czy w ilustracjach do dzieł literackich ekspediujących czytelnika do światów alternatywnych (Pessel 2020). Instruktywny rejestr map „widywanych gdzie indziej" prowadzi (m.in. na swoim profilu na Facebooku) kulturoznawca Igor Piotrowski, żywo zainteresowany tym zagadnieniem jako badacz (zob. np. Piotrowski 2010). Aż prosi się zapytać, gdzie w XXI wieku mapa zawsze jest na swoim miejscu? Ale nie jest to celem tego artykułu. Podobnie jak nie jest nim wdrożenie perspektywy użytkowników czy to map, czy transportu zbiorowego. Kulturoznawca wychodzący od zjawisk współczesnych, lecz diagnozujący je w kontekstach historycznych, nie potrzebuje zapuszczać się w obszary etnografii i badania, jak to nazywa Janusz Barański, żywej kultury (np. żywej kultury pasażerów komunikacji zbiorowej), natomiast powinien skupić się na pograniczach problemowych, przestrzeniach między konwencjonalnymi zagadnieniami naukowymi. Tutaj - na tym, co wyłania się pomiędzy miastem jako projektem urbanistycznym i projekcją władzy (de Certeau 2008: 93-110), instrumentalizującą mapy czy plany, a komunikacją publiczną jako zagadnieniem infrastrukturalnym i organizacyjnym, nadto mającym swoją czasowość.

Po pierwsze, interesuje mnie specyficzny przypadek map „widywanych gdzie indziej": aktualne schematy komunikacji w Warszawie udostępniane przez zarząd transportu. Jak staram się wykazać, stanowią one substytut tego, co w języku angielskim nazywa się transit map, a po polsku, w uzusie PPWK (Państwowego Przedsiębiorstwa Wydawnictw Kartograficznych im. Eugeniusza Romera) z lat 80. XX wieku - planem komunikacji miejskiej. Bezpośrednią inspiracją do namysłu nad siecią komunikacji miejskiej w Warszawie, prowadzonego w aspektach rozwoju terytorialnego i unowocześniania infrastruktury miasta, jest kompendium, którego autor za cel postawił sobie zebranie i scharakteryzowanie wszystkich tego rodzaju planów na świecie. Londyńczyk Mark Ovenden (2015) nie pominął Warszawy, ale usytuował ją w części 
trzeciej, przewidzianej dla swego rodzaju variów i ciekawostek, głównie miast dopiero rozwijających się. Po drugie, zajmują mnie precedensy: historyczne przypadki, gdy za pełnoprawne transit maps posłużyły odpowiednio zademonstrowane publicznie plany miasta. Przypomina to o tezie Karla Schlögla, że pokazywanie czegoś w określonych sytuacjach idzie w parze z ukrywaniem innych faktów (Schlögel 2009: 91-92).

Warto zaznaczyć, że książka Transit Maps of the World Marka Ovendena nie ukazała się w niszy znanej wyłącznie ekscentrycznym klubom miłośników transportu miejskiego. Kompendium opracowane przez Ovendena opublikowało bowiem wydawnictwo Penguin Books, po raz pierwszy w 2003 roku (wydanie tutaj przywoływane stanowi drugą aktualizację i wolno spodziewać się następnych). Ovenden stoi na stanowisku, że schematy komunikacji miejskiej zaliczają się do najliczniej reprodukowanych spośród wszystkich wytworów kartografii - są mapami rzeczywiście masowymi. Co warto podkreślić, Ovenden konsekwentnie uznaje je za mapy, nie zaś za np. infografiki, i w tym względzie podążam jego śladem. Schematy komunikacji mogą uwzględniać przeróżne środki transportu naziemnego (autobusy, tramwaje, trolejbusy, koleje), jednak podstawowa i pierwotna motywacja ich powstawania i rozwijania specyficznego wzornictwa przez zajmujących się nimi grafików wiąże się z metrem, systemami transportu podziemnego. Poruszanie się pod powierzchnią miasta - gdzie nie ma naturalnych punktów odniesienia, a w tunelach przeważnie panują ciemności, słabnie więc lub zupełnie zostaje uśpiona orientacja człowieka w przestrzeni - wymaga szczególnego wsparcia, zmapowania; pasażerowie potrzebują informacji wizualnej, zminiaturyzowanego planu przeprowadzającego ich przez tunele w pożądanym kierunku (Ovenden 2015: 004-007).

Oczywiście trzeba w tym punkcie zastrzec, że kategoria szybkiego transportu szynowego (rapid transit) od czasów założenia metra w Londynie, Budapeszcie czy Paryżu stała się niezwykle pojemna. Jeśli przetłumaczyć zwrot rapid transit wprost "Szybka kolej miejska” w przypadku Warszawy odnosi się on nie do metra samego, lecz do pięciu istniejących linii SKM (Szybka Kolej Miejska) - przejazdów kolejowych organizowanych przez Zarząd Transportu Miejskiego, jednak z wykorzystaniem infrastruktury PKP (Polskie Koleje Państwowe). Abstrahując od tego, że składy metra w różnych metropoliach na świecie, poza dzielnicami centralnymi, wyjeżdżają na powierzchnię czy też kursują otwartymi wykopami, to jednocześnie funkcja metra może być przejmowana bądź współdzielona przez kolejki, odwrotnie, wyniesione nad powierzchnię (nadziemne), np. „L” („elevated”) w Chicago, podwieszana Schwebebahn w Wuppertalu lub kolejki typu light rail, np. Stadtbahn w Bielefeld - krzyżówkę tramwaju i S-bahn (w stylu berlińskim). Im sieć komunikacyjna robi się bardziej skomplikowana, porozgałęziana, im częściej wykorzystuje takie hybrydowe środki transportu, tym silniej zaznacza się konieczność opatrzenia jej legendą i sprowadzenia do przystępnego schematu. Stwarza to olbrzymie pole do popisu dla designerów. Transit Maps of the World potwierdzają, że ten rodzaj projektowania nie ustępuje 
doniosłością aranżowaniu przestrzeni stacji metra czy wkomponowywaniu wiat przystankowych w kontekst urbanistyczno-architektoniczny. Za udane należy uznawać te mapy komunikacji, które okazują są równie rozpoznawalne - i zapadające w pamięć wzrokową - co sam krajobraz danego miasta.

Kluczem do takiego sukcesu jest zastosowanie mądrego, pomysłowego uproszczenia w „interpretacyjnej narracji otaczającego nas świata” pojazdów komunikacji zbiorowej. W tej dziedzinie niepokonanym wzorem pozostaje mapa metra w Londynie, opracowana przez Henry’ego Becka w 1931 roku. Przedwojenny typograficzny "idiom” obowiązuje w miejskim przedsiębiorstwie Transport for London mutatis mutandis do dzisiaj. Badacz transportu Zhan Guo potwierdza, że pasażerowie w Londynie, wybierając najwygodniejsze i najkrótsze połączenia, ufają bardziej tej mapie niż własnej orientacji i znajomości metropolii (Guo 2011: 632). Mapy londyńskiego metra z lat 20. przypominały splątane sznurowadła czy talerz spaghetti, w ogóle nie pomagały pasażerom w ustaleniu przesiadek i drogi do obranego celu. Beck - jakby na przekór rozmachowi lansowanemu w międzywojniu przez art déco - zdobył się na praktyczny minimalizm. Zrezygnował z odwzorowywania geograficznego położenia stacji na rzecz ich wzajemnych odniesień przestrzennych. Uporządkował plątaninę tuneli i linii londyńskiego metra za pomocą poziomych, pionowych i skośnych linii naniesionych na siatkę ośmiokąta; kołami oznaczył węzły (stacje) przesiadkowe. Z jednej strony, znaczenie wszystkich „post-Beckowskich” planów metra w kulturach miejskich i aglomeracyjnych XXI wieku wydaje się ograniczane przez planery internetowe, więc osłabiane „z poziomu smartfona” (warszawski transport publiczny korzysta oficjalnie z wyszukiwarki ,jakdojade.pl”), z drugiej strony - nieustannie poszerza się rzeczywistość warta mapowania tradycyjnym sposobem. Do roku 2015, tj. roku trzeciego wydania kompendium Ovendena, ponad 400 miast na świecie uruchomiło metro, a wiele miast planuje otwieranie kolejnych tras, w tym Warszawa czy Kopenhaga.

Obecność Warszawy w fascynującym, materiałowo wyczerpującym zbiorze Transit Maps of the World może cieszyć, lecz przy tym dostarcza jasnego dowodu na to, że stolicy Polski w początkach XXI wieku brakuje ujednoliconego „zmapowania” transportu publicznego. Nie dorobiła się stolica generalnego schematu transportu publicznego z własnym, rozpoznawalnym stylem graficznym, topograficznym „idiomem". Należy dociec przyczyn takiego stanu rzeczy. A przy tym trzeba zauważyć, że również w przeszłości (w XX wieku) w funkcjach planów komunikacji posługiwano się w stolicy planami miasta z naniesionymi na nie trasami tramwajów i autobusów.

Ovenden przedrukował schemat, który najpewniej wydał mu się stanowić ekwiwalent grafiki o zakresie dorównującym mapom komunikacji w Berlinie, Barcelonie czy Moskwie. O raczej intuicyjnym w tym przypadku działaniu Ovendena (czy też po prostu działaniu po omacku) świadczy to, że znalezioną mapę opatrzył komentarzem złożonym zaledwie z dwóch zdań, z którego można dowiedzieć się, że pokazuje ona „pięć linii tramwajowych i wszystkie kolejki” (Ovenden 2015: 159). W rzeczywistości linii 
tramwajowych ma Warszawa pięć razy więcej, a pociągi, oprócz SKM, nie są w pełni zintegrowane z transportem miejskim - inni przewoźnicy nie honorują biletów jednorazowych i czasowych, wyłącznie okresowe (o odpowiednio wysokiej cenie). Co ciekawe, we wprowadzeniu do trzeciej części Transit Maps of the World Ovenden wymienia nie Warszawę, lecz Gdańsk - jako miasto modernizujące starą infrastrukturę tramwajową (Ovenden 2015: 128). Przedrukowany jest schemat komunikacji tramwajowej Gdańska, w zmniejszonym formacie, bez słowa komentarza - na tej samej stronie znalazły się jeszcze plany komunikacji w Fukuoce, Genui i Glasgow.

Teraźniejsza Warszawa dysponuje trzema fragmentarycznymi schematami. Pierwszy to schemat komunikacji szynowej. To na ten natrafił Ovenden i w Transit Maps of the World zestawił go z miniaturkami prospektywnych planów metra z lat 30. i 80. XX wieku. Symptomatyczne, że w ten sposób zaakcentował, że Warszawa to „miasto historii”: miasto odbudowane, ale nadal „w budowie”, paradoksalne. Pod względem graficznym mapa komunikacji szynowej w Warszawie nawiązuje czytelnie do stylistyki Beckowskiej mapy metra londyńskiego, tyle że maskuje lokalny kompleks braku sieci kolei podziemnej w ścisłym tego zwrotu znaczeniu (Bukowiecki 2012: 54-55). Pierwszą linię dokończono w 2008 roku po 25 latach budowy, druga jest gotowa w połowie (kolejny odcinek na Woli oddano do użytku wiosną 2020 roku). Ovenden dotknął tego kompleksu, zauważając, że przedwojenne plany na całą sieć metra nie ziściły się. A przedstawiały się obiecująco: oficjalny projekt sieci metra z 1927 roku przewidywał „docelowo wybudowanie siedmiu linii metra o łącznej długości $46 \mathrm{~km}$, przy czym 26 km w tunelu, a 20 km na powierzchni” (Jastrzębski 2019: 142).

Na aktualnym schemacie komunikacji szynowej w Warszawie odpowiednikami licznych linii metra są linie tramwajów i pociągów (SKM, podlegającej marszałkowi sejmiku wojewódzkiego spółki Koleje Mazowieckie i samorządowej spółki Warszawskie Koleje Dojazdowe), dzięki czemu sprawia on wrażenie odpowiednio gęstego i całościowego; niczego nie ujmuje prestiżowi miasta aspirującego do statusu europejskiej metropolii. Dwie linie metra, oznaczone grubymi niebieskimi kreskami, prezentują się jak rzeki, a Wisłę, bladoniebieską smugę, trudno by na grafice wypatrzeć nie znając jej biegu. Niezależnie od tych zabiegów, tworzących „narrację interpretacyjną”, i ograniczenia do jednego typu transportu, można powiedzieć, że jest to mapa spełniająca kryteria elementu szaty informacyjnej miasta (Wallis 1979: 101-110). Tworzy uniwersalny język, którym miasto mówi do mieszkańców. Komunikacja nie tylko przewozi, lecz również komunikuje.

Drugi schemat ujmuje linie strefowe, inaczej - podmiejskie, kursujące poza pierwszą strefą, a zatem również pierwszą taryfą biletową. Trudno wskazać powód, dla którego schemat ten byłby szczególnie przydatny mieszkańcom okolic Warszawy, ma jednak pewną wartość eksploracyjną dla badaczy miejskich chcących ustalić, na ile stołeczny transport publiczny współtworzy proces wzmacniania obszaru metropolitarnego, zacieśniania się relacji Warszawy z małymi miastami satelitarnymi 
i miejscowościami o charakterze willowym, na ile zaś musi zacierać skutki gwałtownego przepływu ludności do osiedli podmiejskich: suburbanizacji (urban sprawl) bazującej „na rdzeniu starych wsi” (Kajdanek 2011: 309).

Trzeci schemat to mapa komunikacji dziennej, z aneksem w postaci mapy komunikacji nocnej. Wyróżnia się przede wszystkim tym, że realizuje tendencję horror vacui; z oszałamiającego zmysł wzroku nagromadzenia tras autobusowych i tramwajowych, „kakofonii” amarantowych i czerwonych linii, nazw przystanków i pętli (czyli krańców, przystanków końcowych) wywnioskować można tylko tyle, że sieć warszawskich połączeń ma prawdziwie metropolitarny zakres. Wszystkie trzy schematy są dostępne w wersji elektronicznej1. Olbrzymi plik z tym trzecim stawia opór przy otwieraniu i przeglądaniu nawet szybkim, niemobilnym komputerom.

Nasuwa się pytanie, czemu w ostatnich kilku latach nie powstała koncepcja ujednoliconej mapy warszawskiej komunikacji? Wysiłek włożono natomiast w konkursową procedurę wyboru projektu logo stołecznego transportu. Zwycięski logotyp, tj. litera "t” z ogonkiem przywodzącym na myśl warszawską syrenkę, wzbudził wiele kontrowersji. Szukano jednolitości tam, gdzie potrzebna ani gotowa ona nie była. „Wprowadzenie znaku - tłumaczy współautor, Marian Misiak - nie pociągnęło za sobą (...) zmiany wielu symboli przez jeden czytelny gest. Chcieliśmy, żeby wdrożenie nowego logotypu było poprzedzone konkretnym planem zastąpienia poprzednich znaków" (Misiak 2018: 93-94). Wynika stąd, że Zarząd Transportu Miejskiego (ZTM) w Warszawie uchyla się o dbałości o koherencję szaty informacyjnej w przypisanym mu zakresie, a sieć stołecznego transportu mapuje bez systemowego zaangażowania. Można spekulować, że w ZTM przyjmuje się, że albo pasażerowie, wybierając codzienne środki transportu, kierują się nawykami, albo korzystają z pomocy internetowych; nie trzeba im więc znać systemowych prawidłowości i nieprawidłowości uwidocznionych po zmapowaniu sieci połączeń.

Każda mapa komunikacji jest jak portret miasta (Ovenden 2015: 5) odsłaniający jego duszę albo genius loci, czyli w tym przypadku, by zapożyczyć zwrot od Martiny Löw, niemieckiej socjolożki przestrzeni, „logikę terytorialną” (Löw 2018: 151). Odczytując to jako wskazówkę interpretacyjną, proponuję przyjrzeć się dwóm takim mapom-portretom Warszawy, pochodzącym przy tym z różnych momentów historycznych. Ich porównanie odsłania równocześnie prawidła „logiki terytorialnej” z zasadniczymi uwarunkowaniami rozwoju przestrzennego, jak przemiany w założeniach systemu komunikacji zbiorowej oraz dotykające go niedobory i długotrwałe kompleksy. Celowo rozpatruję materiały powstałe w bardzo różnych okolicznościach, tj. tuż przed wybuchem drugiej wojny światowej i tuż przed końcem Polski Ludowej, i różnorako w swoich epokach wykorzystane w przestrzeni miasta; te materiały kartograficzne

1 Można je obejrzeć na stronie Warszawski Transport Publiczny (https://www.wtp.waw.pl/mapy-schematy); jest to serwis internetowy przeznaczony przez zarząd miasta stołecznego dla jego mieszkańców-pasażerów. 
łączy jednakże to, że zostały wytworzone na krótki czas przed istotnymi cezurami w dziejach miasta.

Plan Sieci Tramwajów i Autobusów m. st. Warszawy z 1938 roku powstał jako jeden z wielu składników wystawy Warszawa. Wczoraj - dziś - jutro w Muzeum Narodowym (Piątek 2016: 229-245). Jak na plan - nie mapę - przystało, zamiast siatki kartograficznej, został wyposażony w siatkę kwadratów; obejmuje administracyjny obszar ówczesnej Warszawy, jednak z podanymi nazwami wyłącznie ulic pryncypalnych. Linie tramwajowe pociągnięto czerwonym kolorem, zaś autobusowe - czarnym. Kontrast do „mapy” Warszawy, odwzorowania jej topografii w tle, jest bardzo dobry, plan spełniał swoje perswazyjne zadanie. Zachowując cechy publikacji kartograficznej, był wytworem przedwojennego wzornictwa. Nie dziwi więc, że na rynku kolekcjonerskim są dostępne reprinty planu z 1938 roku (do wykorzystania np. w funkcji plakatu do dekoracji). Był także instrumentem politycznym w kampanii wyborczej do rady miejskiej; otwarcie wystawy odbyło się 13 października 1938 roku, a wybory 18 grudnia (Drozdowski 2006: 288-290). Modele przestrzeni rzutowane w przyszłość przeważnie są polityczne. „Wybory - objaśnia Jeremy Black (1997: 108) mogą również sprzyjać publikowaniu map, z zamierzeniem kształtowania stronniczych punktów widzenia, nie zaś naukowej analizy przestrzeni".

Bezpośrednim pretekstem do zorganizowania wystawy okazało się ukończenie gmachu Muzeum Narodowego i współpraca Stefana Starzyńskiego ze Stanisławem Lorentzem. Tłumnie odwiedzana przez mieszkańców stolicy ekspozycja stanowiła pewnego rodzaju kontynuację wystawy z 1936 roku, zatytułowanej Warszawa przyszłości. Obie mocno akcentowały optymistyczne warszawskie „jutro”, które rychło okazało się potężnym cywilizacyjnym zerwaniem; przyniosło fizyczne unicestwienie tkanki miejskiej. Paradoks odbudowy polskiej stolicy polegał na tym, że ta miejska tragedia dla powojennych urbanistów i architektów oznaczała możliwość wykazania się w „polu pustym”, wymyślania od nowa "miasta, które przeżyło własną śmierć” i wznoszenia nowych osiedli "na surowym korzeniu”. Na przykład celem przebicia nowej ulicy, budowniczowie nie musieli zmagać się, w przeciwieństwie do Starzyńskiego, z koniecznością wykupu nieruchomości czy też terenu (por. Drozdowski 2006: 42).

Portret Warszawy i jej sieci komunikacji publicznej z końca lat 30. XX wieku jest więc też podsumowaniem procesów i osiągnięć wizerunkowych „Paryża Północy” i jako taki może zostać zestawiony z wydanym drukiem (w skali ok. 1:26 000) przez państwowe wydawnictwo kartograficzne Planem komunikacji miejskiej z 1989 roku, będącym również portretem - Warszawy zbierającej żniwo z całego okresu PRL, a implicite - zapowiedzią i rozrysowaniem tego, co miało wkrótce ulec przekształceniu w warunkach demokracji oraz wolnego rynku.

Rzecz jasna, uwagę o swobodzie budowniczych powojennej Warszawy należy opatrzyć dwoma zastrzeżeniami. Pierwsze wiąże się z ideologicznym kagańcem realnego socjalizmu. W architekturze Warszawy zostawił on, co prawda, ślady 
nieusuwalne - nawet pomimo burzycielskiego zapału np. ministra Radka Sikorskiego - (plac Defilad z Pałacem Kultury, MDM). Nie trwał jednak wcale długo, w odróżnieniu od znacznie dłuższej koniunktury zjawisk, z którą łączy się drugie zastrzeżenie. Zaraz po rewolucji realnego socjalizmu nastała rewolucja realnego modernizmu, którego dziedzictwo, jak pokazała niedawno Joanna Kusiak (2017), doprowadziło w miastach do zjawisk dających się krytykować cytatami wyjętymi z Karty ateńskiej, będącej kluczowym dokumentem eksperckim „czystego” modernizmu. „Wściekły rytm - czytamy w Karcie - razem z prowadzącą do zniechęcenia niepewnością, dezorganizuje warunki życia, przeciwstawiając się słuszności podstawowych potrzeb" (Le Corbusier 2017: 86). Jak uważa Kusiak, doszło do takiego doktrynalnego wypaczenia, ponieważ powojenni architekci, dążący do nowoczesności, „dali się uwieść (...) idei technologicznego postępu” (Kusiak 2017: LXIX). Moderniści - w tym miejscu bez rozstrzygania, kto i na ile był w Polsce Ludowej wiernym uczniem głównego autora Karty ateńskiej - wyrzekli się ludzkiej skali na rzecz nowych technologii, nowych prędkości, w tym lansowania ruchu samochodowego (transportu spalinowego), wielkich osiedli z dala od centrum, odrzucenia przeszłości, więc także tradycyjnie rozumianej ulicy. W tym kontekście warto przypomnieć fakty z dziejów transportu publicznego w Warszawie drugiej połowy XX wieku: wycofanie z ulic miasta trolejbusów (etapami, na przełomie lat 60. i 70.) i ograniczenie torowisk - likwidację tramwajowego połączenia Śródmieścia z Powiślem (1960 rok ) czy Wilanowem (1973 rok). Autobusy były kompatybilne z modernistyczną wizją szybkiego ruchu samochodowego, odpowiadającego na potrzebę docierania do daleko rozlewających się nowych osiedli - to wizja zastępująca starą miarę kroków ludzkich nową, ,prędkością pojazdów mechanicznych” (Le Corbusier 2017: 83).

Duch modernizmu unosił się już nad myśleniem o mieście w Polsce przedwojennej. Warszawa funkcjonalna (2013), całościowa wizja rozwoju stolicy i całego „regionu warszawskiego" z 1934 roku, powstała w kręgu i pod wpływem CIAM (Międzynarodowego Kongresu Architektury Nowoczesnej); wzbudziła entuzjazm i samego Le Corbusiera, i Stefana Starzyńskiego - prezydenta komisarycznego podejmującego wiele decyzji dalekich od apolityczności (zob. Piątek 2016: 128), lecz gospodarza miasta zawołanego. Jeśli inspirowanie się ideami modernizmu przed drugą wojną światową było w Warszawie rodzajem inteligenckiej utopii, po wojnie i po odwilży otrzymało pretekst realizacyjny: tradycyjną zabudowę miast można było przekształcać pod hasłem zwalczania mieszczańskich czy sanacyjnych przeżytków. Dziedzictwo modernizmu i jego stosunku do „szybkości mechanicznych” i projektowania głównych szlaków komunikacyjnych w mieście stanowi swoiste tertium comparationis dla planów komunikacji stołecznej z 1938 i 1989 roku.

Interesujące, że ten drugi, z momentu przełomowego, obrazujący stan komunikacji na dzień 1 czerwca 1989 roku, czyli na trzy dni przed wyborami do tzw. sejmu kontraktowego, nie został potem zastąpiony designerskim schematem ani jako profesjonalna 
infografika zrazu pomyślany. Przeto był to regularny plan miasta, z naniesionymi nań trasami tramwajów i autobusów, z indeksem ulic na odwrocie. Naonczas masowo drukowane plany komunikacji miejskiej w Warszawie - te same, które trafiały do sprzedaży w księgarniach dystrybuujących publikacje PPWK (Polskiego Przedsiębiorstwa Wydawnictw Kartograficznych), obok innych map i atlasów - zaczęto umieszczać „za szybą” na przystankach. W przystankowych wiatach można je było potem oglądać przez całe lata 90. (i później). Z pewnego punktu widzenia urzędnicy odpowiadający za warszawski transport poszli na skróty. Nie brakowało u schyłku PRL znakomitych tradycji wzornictwa i grafików, którzy byliby w stanie zaprojektować całościowy schemat, i to w stylu śmiało konkurującym z londyńskim. Za tym szczególnym kolportażem planu komunikacji w przestrzeni publicznej, poprzez gablotki na przystankach, kryła się głębsza przyczyna.

Ostatnie lata PRL upłynęły w dziedzinie warszawskich przewozów publicznych pod znakiem oczekiwania na oddanie do użytku metra. Dziś mogłoby to z powodzeniem zostać uznane za scenę z filmowej komedii, jednak piszący te słowa, jako uczeń wczesnej klasy szkoły podstawowej był z wycieczką na budowie stołecznej kolei podziemnej, całą klasą zszedł do tunelu i w dziecięcej wyobraźni mógł widzieć wypełniony pasażerami skład (który tym ursynowskim tunelem pomknął dopiero 7 lat później). Toteż w sytuacji przedłużającego się oczekiwania na metro, pasażerom niejako podsuwano pod oczy mapę komunikującą, jaki to wydajny „zbiorkom” ich obsługuje pod koniec lat 80. - mapę z nowymi typami linii autobusowych. To oczekiwanie na metro liczmy tutaj od obietnicy jego wybudowania, złożonej przez generała Jaruzelskiego wkrótce po ogłoszeniu stanu wojennego (1981 rok), nie zaś od zarzuconych planów z czasów prezydentury Bieruta ani tym bardziej od przyrzeczenia dwóch linii, z którego rozliczano już Stefana Starzyńskiego (Drozdowski 2006: 290). Po zniesieniu stanu wojennego rosła potrzeba wykazywania, że system transportu zbiorowego w stolicy kraju, pomimo braku szybkich przewozów podziemnych, jest rozwinięty, efektywny i obejmuje nawet bardzo daleko usytuowane krańce. Na planie z 1989 roku uwagę przykuwa długie ramię linii sięgającej osiedla Mańki-Wojdy. Pnie się ono w próżnię, która za niedługi wcale czas miała okazać się zarzewiem nieładu przestrzennego, „rezerwą" pod chaotyczną urbanizację łanową czy też narolną (należy przez to pojęcie rozumieć zabudowę miejską odtwarzającą formę podłużnych pasów ziemi, świetnie nadających się do orania, wprost jednak przeciwnie do budownictwa komercyjnego) W tym samym świetle należy rozumieć praktykę już współczesną (ze ścisłego końca XX i pierwszych dekad XXI wieku): odgórne wprowadzanie jednoczesnej zmiany wielu tras autobusowych po uruchomieniu następnego odcinka metra, nierzadko wbrew oczekiwaniom i wygodzie pasażerów; budowa kolei podziemnej pozostaje dla magistratu i spółek miejskich odniesieniem tak przemożnym, że już bezrefleksyjnym.

Trudno zakwestionować myśl Karla Schlögla, że mapy tracą swoją aktualność w momencie opublikowania: „Przy sporządzaniu mapy geologicznej różnica kilku 
tysięcy lat nie odgrywa większej roli, jednak podczas przygotowywania mapy pogody różnica paru godzin decyduje o czytelności i precyzji, a co za tym idzie: o użyteczności mapy" (Schlögel 2009: 80). O wydanych przez PPWK mapach stołecznej komunikacji umieszczanych na przystankach (rozłożonych) - lub noszonych w kieszeni czy podręcznym bagażu (złożonych), chociaż to mniej codzienna praktyka - należałoby powiedzieć to samo, nawet ze wzmocnionym akcentem. Pomijając mnóstwo innych poznawczych funkcji strony Trasbus - historia warszawskiej komunikacji miejskiej (trasbus.com), z kronikarską systematycznością prowadzonej przez Bartłomieja Maciejewskiego i Daniela Nalazka, w dziale Kartoteki Linii pokazuje ona dowodnie, jak często i jak wiele korekt oraz dalekosiężnych zmian wprowadzano na przełomie lat 80. i 90. do tras, przede wszystkim autobusów. W związku z tak szybką dezaktualizacją, nie mniejszą zresztą aniżeli obecnie, w Warszawie „w budowie”, mapy komunikacji widziane na przystankach nie mogły z gruntu instruować pasażerów precyzyjnie, jak najłatwiej dotrzeć w wybrane miejsce, podczas gdy z nawiązką służyły politycznej iluzji wydolności systemu przewozów. Jak wiemy, mapy zawsze cechuje pewna wybiórczość i stronniczość, pokazywanie czegoś łączy się z zaciemnianiem albo wymazywaniem (por. Black 1997: 11). Mapy na przystankach nie kłamały w tym znaczeniu, że pokazywały prawdziwy, choć nieuchronnie zdezaktualizowany, układ połączeń, ale nie mogły już powiedzieć tego, co zdradziłyby rozkłady jazdy załączone w legendzie: za małą częstotliwość kursów, niedobory w taborze. Wprowadzanie nowych typów linii nie oznaczało wcale redukcji tłoku, uciążliwości dojazdów na osiedla typu "blokowisko” (Tarchomin, Bemowo, Ursynów i Natolin). Pojawiające się w autobusach i tramwajach naklejki ze sloganem „wzajemna życzliwość łagodzi trudy dojazdów” były więc tyleż demaskatorskie, co ironiczne i cyniczne.

Plan Sieci Tramwajów i Autobusów m. st. Warszawy pokazuje, że w 1938 roku składała się ona z tramwajów, autobusów, kolei państwowych, jak też Elektrycznych Kolei Dojazdowych (protoplastki dzisiejszej WKD) oraz kolejek dojazdowych, mareckiej czy karczewsko-jabłonowskiej; te ślamazarne wąskotorowe ciuchcie przezywano „samowarkami”. Na przedwojennym planie połączenia szynowe i autobusowe dociągnięte zostały do granic miasta. Tam także znajdowały się kluczowe pętle tramwajowe. Trzeba do tego dodać 9 km torowiska zamiejskiego (Warszawa. Wczoraj - dziś - jutro 1938: 40); status podmiejskich miały 4 linie tramwajowe. Co było novum: „dziewiętnastka" do pętli Służew zaczęła dojeżdżać dopiero jesienią 1936 roku, po oddaniu nowego odcinka z Królikarni w kierunku Szop Polskich, a na podmiejską „S” przemianowana została we wrześniu 1938 roku, gdy powstał jeszcze dalej położony kraniec - przy nowym torze wyścigów konnych (inauguracja zawodów w czerwcu 1939 roku). Stary tor działał na Polach Mokotowskich, tuż obok lotniska, z którego w 1934 roku ruch pasażerski przeniesiony został na Okęcie - także w strefę podmiejską. Z tego względu na zajmującym nas tu planie, Pole Mokotowskie przedstawia się wciąż jak pas startowy, nie zaś plac budowy planowanej dzielnicy im. Naczelnika 
Piłsudskiego; resztki lotniska zlikwidowano po wojnie. Inna ważna linia zamiejska docierała do Wilanowa. Przywrócenie tej trasy, czyli zbudowanie od nowa, niedawno zostało zaprojektowane przy aplauzie mediów, lecz realizacja tego projektu wydaje się coraz bardziej niepewna, mimo że „interesariuszami” są tu mieszkańcy prestiżowej - czy też raczej nowobogackiej - dzielnicy Miasteczko Wilanów.

Spośród wszystkich widocznych na planie z 1938 roku środków transportu w Warszawie wyraźnie dominują tramwaje. Ma to potwierdzenie w danych liczbowych. W 1937 roku stolica dysponowała 244 kilometrami torowisk, 29 liniami dziennymi i 9 nocnymi. Tabor zakładów tramwajowych tworzyło 386 wagonów z silnikiem i 316 przyczepnych (rachuba ta nie uwzględnia wagonów towarowych). Tymczasem autobusy, których miasto miało 65, poruszały się po 14 trasach, liczących łącznie 47 kilometrów (Warszawa. Wczoraj - dziś - jutro 1938: 40). Praktyczną miarą dominacji tramwajów, dostrzegalną na planie przygotowanym na wystawę w Muzeum Narodowym, jest obsługiwanie Powiśla, zatem poruszanie się w dół i górę skarpy (tj. skarpy wiślanej na terenie Warszawy). Pokonywanie przez tramwaje stromizny nie jest technicznie niemożliwe, wszakże stało się uciążliwe, gdy po wojnie zaczął wzrastać ruch kołowy i pojazdy spalinowe narzucały coraz to wyższe przyśpieszenia i prędkości (np. w biegu ulicy Książęcej skarpa ma około 20 metrów wysokości). W przypadku przedwojennej trasy do Wilanowa formalnym powodem likwidacji była budowa Wisłostrady, jednej z centralnych arterii komunikacyjnych stolicy (oddanej do użytku 22 lipca 1974 roku). Braki w tym względzie nadrabiano w PRL przez ponad ćwierćwiecze.

Na planie komunikacji z 1938 roku uderza brak takich arterii komunikacyjnych (zarówno Wschód-Zachód, jak i Północ-Południe) i duże zagęszczenie zabudowy w śródmieściu. Odbudowa stolicy z wojennych zgliszczy stworzyła możliwość wydzielenia większości torowisk tramwajowych z jezdni, jednak przed wojną tramwaje w sercu miasta musiały „przeciskać się” pomiędzy innymi uczestnikami ruchu. Stąd katalog wystawy informował o zupełnym wyczerpaniu „przelotności ulic” i „charakterystycznym stopniowym wypieraniu ze śródmieścia tramwajów i zastępowania ich autobusami, lepiej dostosowującymi się do obecnych warunków ruchu ulicznego" (Warszawa. Wczoraj - dziś - jutro 1938: 34). Katalog przy tym dostrzegał „mniejszą zdolność przewozową autobusów w stosunku do tramwajów", dlatego niezbędna zmiana zacznie zachodzić "dopiero po uruchomieniu linii metro, kiedy ruch masowy zostanie w przeważającej części przeniesiony pod powierzchnię ulicy" (Warszawa Wczoraj - dziś - jutro 1938). Starzyński mówił wprost o „pozbyciu się czerwonych powolnych żuków-tramwajów" (Drozdowski 2004: 165). Jak oceniał, planowanie miasta zawsze powinno być skalkulowane na daleką metę, modernizowanie wymusza na gospodarzach pewien śmiały gest: „Toteż, gdy za Sasów projektowano, a za Stanisława Augusta realizowano wspaniałą arterię, Aleje Ujazdowskie, była ona na ówczesne potrzeby na pewno za szeroka. Dziś jest prawie za wąska, a w najbliższej przyszłości już nie zaspokoi potrzeb miasta, tak jak dziś są już za wąskie 
tak ważne arterie jak Krakowskie Przedmieście, Nowy Świat lub Marszałkowska" (Drozdowski 2004: 128).

Na takim tle należy docenić dobrodziejstwo kolei średnicowej w Warszawie, otwartej w 1933 roku. Karta Ateńska przestrzegała: „W wielu wypadkach sieć kolejowa (przy rozroście miasta) stała się poważną przeszkodą dla urbanizacji. Zamyka ona dzielnice mieszkaniowe, pozbawia je pożytecznych kontaktów z ośrodkami życia miejskiego" (Le Corbusier 2017: 170). Innymi słowy, jest krawędzią w rozumieniu Kevina Lyncha (edge), dzieli miasto na odizolowane od siebie obszary (Lynch 2011: 72-77). Bez sprowadzenia ruchu kolejowego w śródmieściu do tunelu, kwestia przepustowości miasta przedstawiałaby się o wiele gorzej. Natomiast o EKD (Elektryczne Koleje Dojazdowe), których stacja końcowa znajdowała się w samym centrum, na ulicy Nowogrodzkiej (w pobliżu skrzyżowania Marszałkowskiej i Alej Jerozolimskich), można by myśleć w kategoriach antenata dla teraźniejszych light rails, hybryd tramwaju i kolejki. Na odcinku warszawskim linia EKD pobiegła, jak to nazywano, systemem tramwajowym, tzn. bezpośrednio ulicami. Ważnym uzupełnieniem systemu komunikacyjnego stolicy tuż przed wybuchem wojny był port; niezależnie od tego, co mówi się na temat wiecznego odwrócenia Warszawy od rzeki, a całego kraju od Bałtyku, Wisła była podówczas drożnym szlakiem komunikacyjnym i dla towarów, i dla pasażerów. W 1937 roku w górę Wisły popłynęło z Warszawy blisko 40 tys. osób, a w dół, ku morzu - ponad 80 tys. (Warszawa. Wczoraj - dziś - jutro 1938: 39).

W powojennej Warszawie rozrost sieci transportu zbiorowego był skorelowany z rozrostem terytorialnym, stopniowym włączaniem kolejnych obszarów podmiejskich w granice miasta. Proces ten zakończyło de facto dopiero przyłączenie do stolicy miasta Wesoła w 2002 roku. W PRL przybywało jednak przede wszystkim połączeń autobusowych. Proces rozbudowy infrastruktury tramwajowej drgnął dopiero po przełomie ustrojowym; tendencję do dyskryminacji tramwaju jako przestarzałego środka komunikacji odrzucono dopiero w obliczu sparaliżowania miasta korkami - gdy pasażerowie zaczęli masowo przesiadać się do własnych samochodów. W 1989 roku, u schyłku Polski Ludowej, po Warszawie kursowało 28 linii tramwajowych stałych i 2 okresowe (wyruszające z krańca „Żerań FSO”), 92 linii autobusowych zwykłych, 18 autobusowych okresowych (tzw. trzysetek, kursujących w dzień roboczy w godzinach szczytu - czy też raczej dojazdów do zakładów pracy), 11 linii pośpiesznych stałych, 3 pośpieszne okresowe, 9 przyśpieszonych, 19 przyśpieszonych okresowych, 12 linii nocnych, 20 podmiejskich, 5 podmiejskich okresowych i uruchomiona w 1983 roku, jakby na prawach kuriozum, jedna linia trolejbusowa, z dawnego Dworca Południowego (dziś Metro Wilanowska) do Piaseczna - można powiedzieć: linia podmiejska, mimo że na całej trasie obowiązywała pierwsza taryfa biletowa.

Plan z 1989 roku zdradza proces generowania rozwiązań zastępczych - by nie powiedzieć, łatania i dojutrkowania w celu podniesienia wydajności środków komunikacji zbiorowej w stolicy - w związku z „eternalnym” brakiem szybkiej kolejki 
podziemnej. Planowanie na daleką metę, postulowane w Warszawie doby Drugiej Rzeczpospolitej, wydaje się z gruntu niewykonalne. Na to, że metro jest w budowie, na planie z 1989 roku wskazuje - oprócz całkowitego wyłączenia z ruchu Alei Niepodległości, ważnej arterii południkowej (N-S) - mnogość pętli autobusowych (zwłaszcza w porównaniu ze stanem obecnym), często urządzanych tylko dla jednej linii. Za takie zastępcze rozwiązanie należy uznać wprowadzenie linii przyśpieszonych. W porównaniu z tradycyjnymi liniami pośpiesznymi obowiązywały w nich najtańsze bilety (bazowa taryfa). Wśród linii przyśpieszonych przeważały okresowe (19 w stosunku do 9 całodziennych). Cztery z nich docierały do pętli na wielkim blokowisku, Ursynowa i Natolina; wspierały tedy pośpieszne linie „U” i „A”, mające mniej przystanków po drodze do śródmieścia, ale i dwukrotnie droższe bilety (druga taryfa) ${ }^{2}$. Znamienne, że dzisiejsza dzielnica Ursynów - wraz ze Służewem nad Dolinką, Okęciem czy Falenicą - nie zmieściła się na pierwszej stronie planu; „ucięty” Ursynów, do obejrzenia po odwróceniu dużego rozłożonego arkusza (u samej góry, powyżej „litanijnego" spisu ulic, placów i linii autobusowych i tramwajowych), sprawia wrażenie kłopotliwego suplementu do bliżej centrum położonych osiedli Mokotowa. Nawiasem mówiąc, w 1987 roku państwowe przedsiębiorstwo kartograficzne wydało osobny plan pn. Warszawa. Ursynów, Natolin. Plan osiedli. Na nim największe stołeczne blokowisko współdzieli ze śródmieściem („z miastem”) axis mundi w postaci budowanej linii metra (wykop oznaczono kropkami, okazano lokalizację poszczególnych stacji), podczas gdy plan z 1989 roku to przemilcza - Ursynów czeka na realne komunikacyjne przyłączenie do stolicy.

Za to plan z przełomowego roku 1989 jeszcze spełnia wymogi propagandy przemysłowej potęgi PRL i społeczeństwa industrialnego. Oto miasto dba o robotników codziennie dojeżdżających do zakładów pracy. Nieprzypadkowo linie okresowe mają krańce w pobliżu fabryk: Polfa (farmaceutyki), Fabryka Domów (wytwórnia prefabrykatów dla budownictwa mieszkaniowego na Wyczółkach), Utrata (Warszawskie Zakłady Telewizyjne, tuż po przełomie ustrojowym przekształcone w spółkę akcyjną Elemis), Ursus (Zakłady Przemysłu Ciągnikowego), Marcelin (fabryka tworzyw sztucznych). „Trzysetki” - zawartości krwi stałych pasażerów nie musimy tu dociekać - nie tyle, jak można by najpierw pomyśleć, dublowały trasy linii zwykłych, wszak np. 170 i 370 obsługiwały tereny magazynowo-produkcyjne na Targówku Fabrycznym, ile rozładowywały tłok - po prostu był to sposób na ukrycie braków w taborze i niewielkiej częstotliwości kursowania wozów poza „uprzywilejowanymi” godzinami. Drugim

2 W 1989 r. normalny bilet na linie zwykłe autobusowe i tramwajowe kosztował 30 zł, na liniach pośpiesznych 60 zł. Dla porównania: w 1988 r. taryfa bazowa wynosiła 15 zł, za przejazd autobusem pośpiesznym trzeba było zapłacić 45 zł, a przyśpieszonym 30 - w skali ca roku kalendarzowego drastycznie wzrosła inflacja, ale nastąpiła jednocześnie pewna „demokratyzacja” dostępu do teoretycznie wygodniejszych połączeń. PPWK umieszczało zasady taryfowe na odwrocie okładki planu - ten z 1988 r. ( „bliźniaczy” wobec planu z 1989 r.) prezentuje stan komunikacji na dzień 31 sierpnia 1988 r. 
aspektem przyznania priorytetu przewozom w dni robocze i godzinach szczytu było niedostosowanie komunikacji miejskiej do spełniania przez miasto jego trzeciej funkcji: wypoczywania (czasu wolnego); wg Le Corbiusiera pozostałe „klucze do urbanistyki” to mieszkanie, praca i poruszanie się (Le Corbusier 2017: 203). Zwłaszcza do korzystania nocą z publicznych autobusów stołeczni pasażerowie byli odgórnie zniechęcani w końcówce PRL; pomijając już okrężne trasy linii nocnych, okazywane przez plan z 1989 roku, obowiązywały w nich nader drogie opłaty za przejazd: aż pięciokrotność biletu na linie normalne dzienne.

A to, że efekt ideologiczny brał górę nad pragmatyką w zarządzaniu mobilnością w mieście (zob. Black 1997: 113-115) poświadcza fakt, że fabryka ciągników rolniczych w Ursusie - między 1952 a 1977 rokiem samodzielnym mieście - nie była połączona w 1989 roku żadnym autobusem pośpiesznym. Problem niedostatecznego skomunikowania Ursusa z centrum stolicy rozwiązywany jest właściwie do dzisiaj. Z przyczyn politycznych nie widać na planie z 1989 roku kolejowej bocznicy, łączącej szlak Warszawa-Radom ze Stacją Postojowo-Techniczną na Kabatach (tzn. elektrowozownią i zapleczem techniczno-remontowym metra), mimo że precyzyjnie odwzorowana została trasa bocznicy do Huty Warszawa; połączenie torów w tunelach podziemnych z naziemną siecią kolejową nabrałoby strategicznego znaczenia podczas konfliktu zbrojnego (Układ Warszawski vs Zachód). Natomiast linie podmiejskie jedynie na Pradze, w Warszawie prawobrzeżnej, mają przystanki początkowe położone nieperyferyjnie (Dworzec Wschodni; plac Leńskiego, obecnie plac Hallera). Naonczas suburbanizacja jest w Polsce jeszcze ideą obcą, a komunikacja z miasteczkami satelitarnymi - cedowana na kolej i „pekaesy” (osobne przedsiębiorstwo - Państwowa Komunikacja Samochodowa). Im bliżej centrum, tym sieć połączeń gęstsza.

Niemniej jednak na planie komunikacji miejskiej z 1989 roku staje się już w pełni widoczne zrealizowanie w dobie Polski Ludowej koncepcji miasta osiedlowego, to jest rozbicie „burżuazyjnej” jedności i spójności śródmieścia, pielęgnowanej przez miasta na Zachodzie (zob. Wallis 1979: 18-31). Co prawda, Trasa Toruńska (dziś część ekspresowej obwodnicy Warszawy), inwestycja mająca w północnej części miasta odciążyć Trasę Łazienkowską, oddaną do użytku 22 lipca 1974 roku, urywa się nagle przy pętli tramwajowej Annopol - jako że w stanie wojennym przerwano prace budowlane (wznowiono je już po przełomie), ale przez to widoczne stają się również pokaźne "rezerwy” pod nową zabudowę - to eldorado developerów znane będzie w Warszawie doby prywatyzacji i reprywatyzacji jako Białołęka. Przestrzenna organizacja warszawskiej społeczności przyswoiła wówczas wzór: segment (bliźniak lub mieszkanie) na przedmieściu plus dojazdy samochodem (zob. Le Corbusier 2017: 177), co zakrawało na naśladowanie Ameryki w kapitalizmie, najczęściej bez kapitału. Tymczasem na planie z 1989 roku nazwa przyszłej dzielnicy Białołęka zapisana jest mniejszą czcionką pomiędzy członami nazwy „Praga Północ”. W tym świetle nie dziwi to, że nazwa drugiej starej, rozległej dzielnicy w prawobrzeżnej Warszawie graficznie 
umieszczona została w dzisiejszym Wawrze, a więc tam, gdzie system komunikacji zbiorowej rzednie. Długo po decentralizacji struktury samorządowej i dzielnicowej, przeprowadzonej w latach 90., sprawy mają się tam podobnie.

To opowiedziawszy, można wrócić do kwestii kardynalnych, zarysowanych we wstępie. Dzieje idei graficznego odwzorowania terenu są długie i bogate, ale to w XX wieku - co też poświadcza literatura poświęcona zagadnieniu mapy, zarówno jako narzędzia kartograficznego, jak i społecznego artefaktu, której cząstkę tutaj przywołano (Schlögel 2009; Black 1997) - szczególnej intensyfikacji uległy procesy uprzestrzennienia poznania. Zwłaszcza wobec nowoczesnej dominacji ośrodków miejskich i wielkich aglomeracji, poglądowość stopniowo stawała się nieodłącznym elementem wizualizacji, konceptualizacji i rozumienia licznych zjawisk i procesów ze zróżnicowanych dziedzin życia. W rezultacie tych procesów w obecnym stuleciu rozmaite mapy i schematy, takie jak transit maps, są utożsamiane z poznaniem danej przestrzeni. Ma ono jednakże swoje ograniczenia. Abstrahując od tego, że szeroko pojęte nauki o kulturze przyczyniają się do metaforyzowania praktyk kartograficznych, jednocześnie mają wymierne zasługi w refleksyjnym odsłanianiu tych poznawczych ograniczeń (Piotrowski 2010). To, że mapy i plany zaliczają się do narracji będących interpretacjami (Galik 2018), nie jest jedynie retoryczną figurą sformułowaną pod przemożnym wpływem dziedzictwa postmodernizmu, ale przede wszystkim tezą o istotnym potencjale krytycznym. W tym artykule zostało to okazane na przykładzie Warszawy, gdzie na mapowaniu przestrzeni miejskiej i transportu publicznego w wyjątkowy sposób zaważyły historia i polityka.

Czy to za sanacji, gdy snuto ambitne, daleko wybiegające w przyszłość plany modernizacji polskiej stolicy, czy w Polsce Ludowej, gdy miasto to w warunkach gospodarki planowo mozolnie dźwigano z gruzów, masowy z istoty charakter planów komunikacji miejskiej (por. Ovenden 2015), w różnych formach zastępczych, czyli substytutów map na miarę londyńskiego dzieła Becka, wykorzystywany był w celu oddziaływania publicznego. Co najwyżej zmieniają się niedostatki, kompleksy i wyobrażenia o tym, co słuszne w planowaniu miasta (np. spór o wyższość transportu szynowego bądź autobusowego i jego miejsce w śródmieściu) skrywane pod woalem tego, co mapy jawnie pokazują. W tej perspektywie okoliczność, że współczesna Warszawa wciąż nie ma jednolitego planu komunikacji, planu z prawdziwego zdarzenia, każe myśleć o braku dobrej mediacji między miastem jako projektem urbanistycznym i projekcją władzy urzędników, mającą podstawę w komunikacji społecznej (zob. de Certeau 2008), a komunikacją miejską rozumianą „twardo”, realistycznie - jako sfera infrastrukturalna, technologiczna i organizacyjna. Czynnik propagandowy przestał odgrywać rolę, ale nowe, oryginalne i politycznie neutralne sposoby mapowania dla pasażerów najprostszej drogi do celu i komunikowania cech stołecznego systemu transportu widać nie są jeszcze gotowe. Całkiem prawdopodobne, że jest to stan nieśmiałości, z której Warszawę wyrwie dopiero uruchomienie trzeciej lub nawet czwartej linii metra. 
Plany i mapy dezaktualizują się, ale niektóre wizje rozwoju miejskiego i towarzyszące im kontrowersje powracają, nierzadko w zaskakujących momentach i oprawach. Zobaczenie następstw tych idei w formie obrazu, więc poprzez zmapowanie, bywa bardziej pouczające od polemiki w dyskursach. Dość powiedzieć, że w 2018 roku Janusz Korwin-Mikke, jako kandydat na prezydenta stolicy, z pochwały autobusów próbował uczynić świeżą sensację: „Tramwaj to sobie może jeździć do Piaseczna czy na Młociny, a nie być zawalidrogą w centrum" (Dybalski 2018).

\section{Bibliografia}

Barański, J. (2008). Kulturoznawstwo - nowa superdyscyplina nauk o człowieku?. W: A. Pankowicz. J. Rokicki, P. Plichta (red.), Tożsamość kulturoznawstwa (s. 35-44). Kraków: Wydawnictwo Uniwersytetu Jagiellońskiego.

Black, J. (1997). Maps and Politics. London: Reaktion Books.

Bukowiecki, Ł. (2012). Metro-projektowania warszawskie. Historia planowania bezkolizyjnej kolei miejskiej w Warszawie. Kultura Współczesna, 2(73), 49-60.

Chmielewski, J., Syrkus, Sz. (2013). Warszawa funkcjonalna. Przyczynek do urbanizacji regionu warszawskiego. Warszawa: Centrum Architektury.

de Certeau, M. (2008). Wynaleźć codzienność. Sztuki działania (przeł. Katarzyna Thiel-Jańczuk). Kraków: Wydawnictwo Uniwersytetu Jagiellońskiego.

Drozdowski, M.M. (red.) (2004). Archiwum Prezydenta Warszawy Stefana Starzyńskiego. Warszawa: Oficyna Wydawnicza RYTM, Towarzystwo Miłośników Historii.

Drozdowski, M. M. (2006). Starzyński. Legionista, polityk gospodarczy, prezydent Warszawy. Warszawa: Wydawnictwo Iskry

Dybalski, J. (2018). Wybory 2018. Janusz Korwin-Mikke: Usunąć tramwaje z centrum. Pozyskane z portalu "Transport Publiczny": www.transport-publiczny.pl/wiadomosci/wybory-2018-janusz-korwinmikke-usunac-tramwaje-z-centrum-59370.html.

Galik, P. (w rozmowie z A. Mateją) (2018). Mapa ma moc. Znak, 758-759, 14-21.

Guo, Z. (2011). Mind the Map! The Impact of Transit Maps on Path Choice in Public Transit. Transportation Research. Part A, Policy and Practice, 45(7), 625-639. DOI: 10.1016/j.tra.2011.04.001.

Jastrzębski, J. (2019). Sto lat warszawskiego metra. Od pomysłu do realizacji. Warszawa: Skarpa Warszawska.

Kajdanek, K. (2011). Suburbanizacja w Polsce - pejzaż społeczno-przestrzenny. Przegląd Socjologiczny, 60, 2-3, 303-320.

Kalbach, J. (2017). Mapowanie wrażeń. Kreowanie wartości przy pomocy ścieżek klienta, schematów usług i diagramów (przeł. P. Janicki). Gliwice: Hellion.

Kusiak, J. (2017). Wściekły rozwój miasta kontra nadopiekuńczy rozsądek utopii. W: Le Corbusier, Karta ateńska (przeł. G. Piątek i in.), LXI-LXXXII. Warszawa: Centrum Architektury.

Le Corbusier (2017). Karta ateńska (przeł. G. Piątek i in.). Warszawa: Centrum Architektury.

Lynch, K. (2011). Obraz miasta (przeł. T. Jeleński). Kraków: Archivolta.

Löw, M. (2018). Socjologia przestrzeni (przeł. I. Drozdowska-Boering). Warszawa: Wydawnictwa Uniwersytetu Warszawskiego. 
Misiak, M. (w rozmowie z A. Gruszczyńskim) (2018). Czytelny gest. Znak, 758-759, 93-97.

Ovenden, M. (2015). Transit Maps of the World. New York: Penguin Books.

Pessel, W. K. (2020). Uporczywe kartografie i mapy z Doliny Muminków. Prace i Studia Geograficzne, 64(4), 53-65

Piątek, G. (2016). Sanator. Kariera Stefana Starzyńskiego. Warszawa: Wydawnictwo W.A.B.

Piotrowski, I. (2010). Słowo, obraz, terytorium. W stronę kulturowej analizy map. Communicare. Almanach Antropologiczny, 3, 125-138.

Schlögel, K. (2009). W przestrzeni czas czytamy. O historii cywilizacji geopolityce (przeł. I. Drozdowska, Ł. Musiał). Poznań: Wydawnictwo Poznańskie.

Wallis, A. (1979). Informacja i gwar. O miejskim centrum. Warszawa: Państwowy Instytut Wydawniczy.

Warszawa. Wczoraj - Dziś - Jutro. Przewodnik i Plan Warszawy. Warszawa w liczbach (1938). Warszawa: Drukarnia miejska.

\section{Streszczenie}

W Warszawie brakuje jednej generalnej mapy środków transportu publicznego o łatwo rozpoznawalnej formie graficznej. Prezentujący podejście kulturoznawcze i historyczno-kulturowe artykuł służy przyjrzeniu się współczesnym substytutom takiego schematu, jak również zawiera analizę dwóch dwudziestowiecznych przypadków publicznego wykorzystania planów miasta jako map sieci komunikacji zbiorczej. Ponieważ, jak dowodzi autor, są to praktyki chwalenia się sukcesami w modernizacji stolicy, a zarazem ukrywające mankamenty i kompleksy (zwłaszcza brak kilku linii metra), ich analiza tworzy pretekst do refleksji nad przestrzennym i infrastrukturalnym rozwojem miasta, m.in. w kontekście dziedzictwa modernizmu i zapoznanej krytyki transportu spalinowego w Karcie Ateńskiej.

Słowa klucze: mapa, miasto, przestrzeń, Warszawa, refleksja kulturoznawcza i historyczno-kulturowa

\section{Summary}

Warsaw lacks a single general transit map with an easily recognizable graphic form. The article, presenting a cultural and historical approach to the issue, points out contemporary substitutes for such a scheme and analyzes two twentieth-century cases of the public use of city plans as maps of public transport networks. Since these are practices of boasting of successes in modernizing the capital city while its shortcomings are concealed, the analysis provides a pretext for reflecting on the city's spatial and infrastructural development. The argument runs in the context of the legacy of modernism, the Athens Charter and critique of motor transport in cities

Keywords: map, city, space, Warsaw, reflection on culture and culture in historical aspect

Translated by Author 
